\title{
STATE AND PERSPECTIVE OF TRANSPORT GEORGIA
}

\author{
G. Tkeshelashvili, Professor, Head of the Department of Management of Mechanical Engineering and \\ Transport of Georgian Technical University \\ G. Zangurashvili, doctoral candidate of mechanical engineering and transport department of \\ Georgian Technical University
}

DOI: https://doi.org/10.31435/rsglobal_ijite/30042019/6450

\section{ARTICLE INFO}

Received 20 February 2019

Accepted 12 April 2019

Published 30 April 2019

\section{KEYWORDS}

economy, management, transport, logistics, information technology. \begin{abstract}
Georgia belongs to an economically backward state. GDP per capita per capita is just a little over $\$ 4000$, while the world average is more than $\$$ 10000. It is natural that all possible resources for the economic development of the country should be utilized. One of the assemblies is transport due to the favorable geographical location of Georgia. Despite this, the contribution of the transport to the country's GDP is very low.

The dynamics of recent years decrease in volume of cargo transported to all types of transport, as well as circulating turnover. This can be solved by implementing macroeconomic events such as development of market infrastructure; Introduction of modern software packages; Perfection of taxation system in its direction and liberalization, improvement of credit and financial system; By establishing a flexible system of business regulation and dispute settlement.
\end{abstract}

Citation: G. Tkeshelashvili, G. Zangurashvili. (2019) State and Perspective of Transport Georgia. International Journal of Innovative Technologies in Economy. 3(23). doi: 10.31435/rsglobal_ijite/30042019/6450

Copyright: (C) 2019 G. Tkeshelashvili, G. Zangurashvili. This is an open-access article distributed under the terms of the Creative Commons Attribution License (CC BY). The use, distribution or reproduction in other forums is permitted, provided the original author(s) or licensor are credited and that the original publication in this journal is cited, in accordance with accepted academic practice. No use, distribution or reproduction is permitted which does not comply with these terms.

Introduction. Georgia's economic situation is actually improving, but it's still far from desirable. Suffice it to say that in terms of per capita with a volume of GDP, Georgia is several times behind not only the leading industrialized countries, but also the world average. According to the estimates of international financial organizations and the UN, this indicator looks as follows (see Table 1).

Naturally, because of such a lagging economic situation, it is imperative to achieve rapid economic development, to ensure approximately the rate that countries called "Tigers of Asia" had in 1990-2010, and in recent years have been Spain, Ireland and other similar countries. This can be achieved when modern technologies are used with these resources, such as natural, financial, geographic, and human resources. The use of computer technology occurs in all places and at all stages of production, beginning and understanding, and ending with the delivery and realization of products.

Separately, it is necessary to note the geopolitically accessible position, and below we will talk about using this advantage.

Georgia is small in terms of territories and sparsely populated in terms of population, but a short road passes through its territories connecting Europe and Asia, in accordance with which use has been happening since ancient times, from the period of elinic and Roman civilizations. And then, when Georgia was developed economically and politically in the middle ages. And then, when Georgia was part of the Russian Empire. Used now and after independence, but apparently not enough. As a result, the share of transport in Georgia's GDP is small and small against the background of the economy, when the environment of this economy can bring results especially if we take into account the status of a maritime country, the wealth of which many countries do not have. 
Table 1. GDP in some states, $\$$ thousand/person ${ }^{1}$

\begin{tabular}{|c|c|c|c|c|c|c|c|c|}
\hline \multicolumn{3}{|c|}{$\begin{array}{l}\text { International Monetary Fund } \\
\text { estimates }\end{array}$} & \multicolumn{3}{|c|}{ World Bank estimates } & \multicolumn{3}{|c|}{ UN estimates } \\
\hline 1 & Luxembourg & 105803 & 1 & Luxembourg & 104,103 & 1 & Monaco & 173377 \\
\hline 2 & $\$_{\text {Switzerland }}$ & 80590 & 2 & * Macao & 80,893 & 2 & Lichtenstein & 152933 \\
\hline - & * Macao & 77451 & 3 & $4_{\text {Switzerland }}$ & 80,190 & 3 & Luxembour & 113373 \\
\hline 3 & 들 & 74940 & 4 & Norway & 75,505 & 4 & Norway & 103586 \\
\hline 4 & Ireland & 70638 & 5 & 듬 Iceland & 70,057 & 5 & Qatar & 93352 \\
\hline 5 & Spain & 70332 & 6 & Ireland & 69,331 & - & * Macao & 91377 \\
\hline 6 & Qatar & 60804 & 7 & Qatar & 63,506 & 6 & $\psi_{\text {Switzerland }}$ & 84854 \\
\hline 7 & 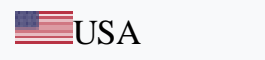 & 59501 & 8 & 淎USA & 59,532 & 7 & Australia & 65600 \\
\hline 8 & Singapore & 57713 & 9 & Singapore & 57,714 & 8 & Sweden & 60566 \\
\hline 9 & Denmark & 56444 & 10 & DDomenic & 56,308 & 9 & $D_{\text {Denmark }}$ & 59921 \\
\hline 10 & Australia & 55707 & 11 & FAustralia & 53,800 & 10 & ڤ̀ San-Marino & 57293 \\
\hline 11 & Eweden & 53217 & 12 & $\forall$ Sweden & 53,442 & 11 & Singapore & 54649 \\
\hline 12 & Nederland & 48345 & 13 & คै- San-Marino & 49,664 & 12 & $\overline{\bar{E}}$ USA & 52392 \\
\hline 13 & คै San-Marino & 47405 & - & Average & 10714 & 13 & $\|+$ Canada & 52270 \\
\hline - & Average & 10038 & 108 & $+{ }^{+}$Georgia & 4078 & - & Average & 10553 \\
\hline 110 & $\div+$ Georgia & 4098 & & & & 117 & $\because$ Georgia & 3875 \\
\hline
\end{tabular}

Main part. The dynamics of the transport sector in Georgia in recent years has been characterized by a downward trend. And there are many reasons for this. Of these, we see two directions: the management of insufficient organizational work to attract transit goods and the reduced demand for imported raw materials for the domestic economy, materials and complex products.

Dynamics of transport according to official statistics is visible in table 2 and 3.

Table 2. The transfer of goods in accordance with the modes of public transport, (thousand of tones) ${ }^{2}$

\begin{tabular}{|c|c|c|c|c|c|}
\hline \multirow{2}{*}{ Years } & \multirow{2}{*}{ Total } & \multicolumn{4}{|c|}{ Including } \\
\cline { 3 - 6 } & & Railway & Automotive & Marine & Airy \\
\hline 2011 & 48926.8 & 20123.4 & 28794.1 & 8.1 & 1.2 \\
\hline 2012 & 49190.8 & 20076.0 & 29110.8 & 3.6 & 0.4 \\
\hline 2013 & 47616.4 & 18185.0 & 29431.0 & - & 0.4 \\
\hline 2014 & 46445.1 & 16673.3 & 29754.7 & - & 17.1 \\
\hline 2015 & 44247.1 & 14142.7 & 30082.0 & - & 22.4 \\
\hline 2016 & 42318.9 & 11881.7 & 30412.9 & - & 24.3 \\
\hline 2017 & 41507.4 & 10672.5 & 30747.4 & - & 87.5 \\
\hline
\end{tabular}

${ }^{1}$ List of countries by GDP (nominal) per capita. Website:

https://en.wikipedia.org/wiki/List_of_countries_by_GDP_(nominal)_per_capita. Verified12.02.2019.

${ }^{2}$ National Statistics Office of Georgia. Statistical Year 2018. Tbilisi, 2018 
Table 3. Exchange of public transport in accordance with the modes of transport, (million of tones $-\mathrm{km})^{1}$

\begin{tabular}{|c|c|c|c|c|c|}
\hline \multirow{2}{*}{ Years } & \multirow{2}{*}{ Total } & \multicolumn{4}{|c|}{ Including } \\
\cline { 3 - 6 } & & Railway & Automotive & Marine & Airy \\
\hline 2011 & 6690.0 & 6054.8 & 628.4 & 5.3 & 1.5 \\
\hline 2012 & 6616.8 & 5976.6 & 637.3 & 2.4 & 0.5 \\
\hline 2013 & 6172.4 & 5525.9 & 646.1 & - & 0.4 \\
\hline 2014 & 5672.4 & 4987.6 & 655.1 & - & 29.7 \\
\hline 2015 & 4966.9 & 4261.3 & 664.3 & - & 41.3 \\
\hline 2016 & 4140.9 & 3423.1 & 673.6 & - & 44.2 \\
\hline 2017 & 3796.1 & 2963.3 & 683.0 & - & 149.8 \\
\hline
\end{tabular}

As can be seen from the above data, the transfer of goods from an average-use transport in total reduced from 2011 to $48,926.8$ thousand tons to $41,507.4$ tons by 2017 . The indicator of commodity turnover looks more highly, where in the analogous period; the trade turnover went down from 6,690.0 million tons of $\mathrm{km}$ to 3,796.1 million tons of $\mathrm{km}$, that is, twice.

The decrease was mainly caused by the deterioration of the railway transport indicator, where in 201120123.4 thousand tons of goods were transferred, and in 2017 only 10672, 5 thousand tons, that is, the volume of the transferred goods was half as much, and as for the turnover, about position.

Separately, it should be noted indicators of sea transport. Georgia is a rare country that has access to the sea, has two active ports of Batumi and Poti, the terminals of Kulevi and Supsa, but does not have a sea flow. Accordingly, the volume of the transferred goods by sea transport is statistically zero after 2012.

General indicators of seaports and terminals are as follows:

1. Port of Batumi - the number of transferred goods in 2015 is 5.7 million tons; the number of recycled containers in 2015 - 54,695 TEU ( 1 TEU - 20 feet - 6.1 meters); patency of the container terminal - 100,000 TEU per year; tourist terminal traffic is 180,000 per year; in February 2008, Kaztransoila's partner, Ltd Batumi Industrial Holding, bought a 100\% stake in Batumi's fuel and terminal shares and the right to the exclusive management of the Batumi sea station for 49 years.

2. Port of Poti - in 2015 the amount of processed goods is 6.8 million tons; amount of recycled container in 2015 - 325.121 TEU; patency of the terminal terminal is 400,000 TEU per year. 51\% of the port of Poti in 2008 and the right to manage the port for a period of 49 years was bought by the Arab company Rakia (RAK Investment Authority). Then the company bought the remaining share of the port and became the owner of a $100 \%$ stake in the company. In April 2011, Rakia sold $80 \%$ of the port of Poti to the Danish partner Ap Moller Maersk Group, Apm Terminals, and transferred from the port management.

3. Terminal Kulevi - in 2015, the number of processed goods is 2.5 million tons; terminal throughput per year is up to 10 million tons; In January 2007, Kulevi Fuel Terminal bought the Socar fuel company of the Azerbaijani state.

4. Terminal Supsa - the number of processed goods in 2015 - 4.2 million tons; annual throughput of 7 million tons; On April 17, 1999, in Supsa, the Supsa terminal was opened, the final fuel point of the Bako-Supsa terminal. The terminal includes 4 tanks, each with a volume of 40,000 tons of fuel. ${ }^{2}$

The depth of both ports operating in Georgia does not allow for the maintenance of ships. The maximum depth of the port of Batumi is $11.5 \mathrm{~m}$, and Poti is only $12.5 \mathrm{~m}^{3}$ But the latter becomes sandy and needs permanent purification, which has not happened in the last few years, so the maximum depth of ships in the port of Poti does not exceed $8.4 \mathrm{~m}$.

Naturally insufficient depth causes a specific complication, since the volume of sea transshipment and intensity are constantly evolving, as a result, it is possible to use high-speed ships, whose services cannot be provided by the operating port of Georgia.

The main competitors of the Georgian seaports are the ports of Novorossiysk of the Russian Federation and Tuapse and the Turkish Samsung. The capacity of the port of Novorossiysk, as a result, at the end of the implemented upgrades, up to 140 million tons a year and its almost $100 \%$ utilization

\footnotetext{
1 oj32

${ }^{2}$ Internet portal bpn. Georgian ports. site:https://www.bpn.ge/article/20177-sakartvelos-portebi/;

${ }^{3}$ okoladze T. The state of marine ports and development problems. Dissertation. The 2012. p. 38, 58;
} 
is carried out. The maximum depth of $24.5 \mathrm{~m}$, which makes it possible to take any ship. ${ }^{1}$ The capacity of the port of Tuapse is relatively less and can process only 20 million tons of goods per year. As for the port of Samsung, its capacity as a result of reconstruction has increased to 40 million tons. ${ }^{2}$

The use of Georgia's sea potential is also possible through the construction of the deep port of Anakli, the implementation of which has already begun, but against the background of recent events, there are large confrontations. In order to improve the business environment, they took into account special discounts for the port of Anakliy, which increased its importance. ${ }^{3}$

Only pipelines are fully operating in the transshipment Georgia. The transit road that borders Georgia represents the most desirable route for delivering Caspian carbohydrates to international markets.

Transportation of fuel, fuel products and gas through pipelines is carried out through Georgia. Azerbaijan, as well as the whole Caspian region, which is rich in energy resources, is isolated from users of world markets and is motivated to choose independent export routes and go through other manufacturers' countries (respectively, competitors).

Georgia has an important transit potential for the fact that international wounds additionally received carbohydrate resources from the Caspi region and Azerbaijan.

Azerbaijan, Georgia and Turkey have established strategic cooperation for transit projects for the Caspian energy resources, in particular, Bako-Supsa (WREP), Bako-Tbilisi-Jeihani (BTC) and Bako-Tbilisi-Erzrum) in the form of pipelines.

Also through Georgia passes the so-called pipeline of the main gas of the Northeast, from where gas is delivered from Russia to Armenia.

As for road transport, the total transferred goods are quite high (30,747 million tons in 2017), but its absolute majority goes for domestic traffic, and in the defense goods, the share of auto transport to Georgia is rather insignificant. Therefore, the turnover indicator is rather low, only 683 million tons, which is 5 times less than the same indicator of the railway.

The reasons for the low transport sector in Georgia are as follows:

- Insufficient development and correctness of the road infrastructure;

- Low technical parameters of transport means and non-compliance with European standards

- High tariffs for the transport of goods;

- Cons of the business environment in transport, which do not stimulate the rapid development of the transport sector;

- The complexity of the use of modern-leading methods of management and logistic and more.

Conclusions. For the purpose of maximizing the transport and transit potential of Georgia, the macroeconomic environment is first of all necessary in the following groups:

- Market Infrastructure Development - Free market relations declared in Georgia but can not operate any commodity exchange, there are no labor exchanges, and the volume of shares quoted on the securities exchange is critically small;

- Tax system - it is in line with tax tariffs of Western European and EU Member States, but does not provide a differential approach except those territorial entities with a status of free economic zone. Our tax system does not involve differentiation of tax tariffs in the sectoral context, which negatively affects the development of sectors for which the country has favorable geographical and natural conditions;

- Failure of credit-finance system - In Georgia, high amounts of national currency lari rate fluctuation in relation to freely convertible currencies, there is a high interest rate on the bank loan and less reinforcing business development;

- Business lawful regulation and dispute settlement system - There is no single arbitration tribunal in the country and the dispute between the financial subjects will be discussed by the Citizens' Citizen's Collegium of Common Courts, where the cases are diligently delayed, and it lasts for several years.

\footnotetext{
${ }^{1}$ Wikipedia. Новоросииск. Novorossiysk. Website: https://en.wikipedia.org/wiki/Novorossiysk;

${ }^{2}$ Website: https://web.archive.org/web/20140328134911/http://www.tcdd.gov.tr/tcdding/samsun_ing.html; verified 20.02.2019.

${ }^{3}$ Mamuka Khazaradze - Anaklia port will have its own legislation - we want to be an analogue of the London arbitration in this zone. M. Casseradze Speech at Caucasus University Website: https://www.interpressnews.ge/ka/article/533208mamuka-xazaraze-anakliis-ports-tavisi-kanonmdebloba-ekneba-gvinda-rom analogi. Verified 20.02.2019; verified 20.02.2019. am-zonashi-iqos-londonis-arbitrazhis-
} 


\section{REFERENCES}

1. List of countries by GDP (nominal) per capita. Website https://en.wikipedia.org/wiki/List_of_countries_by_GDP_(nominal)_per_capita;

2. National Statistics Office of Georgia. Statistical Year 2018. Tbilisi, 2018;

3. Internet portal bpn. Georgian ports. site:https://www.bpn.ge/article/20177-sakartvelos-portebi/;

4. Kokoladze T. The state of marine ports and development problems. Dissertation. The 2012. p. 38, 58;

5. Wikipedia. Novorossiysk. Website: https://en. wikipedia.org/wiki/Novorossiysk;

6. Website: https://web.archive.org/web/20140328134911/http://www.tcdd.gov.tr/tcdding/samsun_ing.html;

7. Mamuka Khazaradze - Anaklia port will have its own legislation - we want to be an analogue of the London arbitration in this zone. M. Casseradze Speech at Caucasus University Website: https://www.interpressnews.ge/ka/article/533208-mamuka-xazaraze-anakliis-ports-tavisi-kanonmdebloba-eknebagvinda-rom am-zonashi-iqos-londonis-arbitrazhis-analogi. Verified 20.02.2019;

8. Gochitashvili T. Oil and gas capacity pipelines (existing and prospective). Tbilisi 2014. Website: http://weg.ge/sites/default/files/1.-energy-transit-projects.pdf. Verified 20.02.2019. 